\title{
A new species of Phrynopus (Anura, Strabomantidae) from Peru, with comments on the osteology of the genus
}

\author{
Linda Trueb ${ }^{1}$ and Edgar Lehr ${ }^{2}$ \\ 1 Division of Herpetology, Biodiversity Research Center, and Department of Ecology and Evolutionary Biology, The \\ University of Kansas, Lawrence, Kansas 66045-7561, USA. E-mail: trueb@ku.edu. \\ 2 Staatliche Naturhistorische Sammlungen Dresden, Museum für Tierkunde, Königsbrücker Landstrasse 159, D-01109 \\ Dresden, Germany. E-mail: edgar.lehr@snsd.smwk.sachsen.de.
}

\begin{abstract}
A new species of Phrynopus (Anura, Strabomantidae) from Peru, with comments on the osteology of the genus. A new, small species of Phrynopus is described from the eastern slopes of the Cordillera Oriental just north of the Río Huallaga in central Peru. The species resembles $P$. montium, but is distinguished from it and other congeners by its spatulate snout. The anterior end of the maxillary arcade is broadly rounded in dorsal view, and composed of wide premaxillae that bear extraordinarily large alary processes that are deflected posteriorly at an acute angle. The configuration of the premaxillae accounts for the wide, depressed snout in this species, which in other osteological features resembles P. montium. The osteology of Phrynopus montium is described in some detail in comparison to the new species, with the intention of establishing a baseline for future morphological studies and taxonomic descriptions of strabomantine anurans of this and related genera.
\end{abstract}

Keywords: Anura, Strabomantidae, Strabomantinae, species description, Phrynopus montium, osteology, Peru.

\section{Introduction}

In their revision of Brachycephalidae (sensu Frost et al. 2006), Hedges et al. (2008a) erected a new taxon, Terrarana, for the 843 species of New World direct-developing frogs, of which Phrynopus is one genus. Phrynopus is one of 16 genera and 490 species placed in the large South American subfamily Strabomantidae,

Received 4 June 2008.

Accepted 1 July 2008.

Distributed September 2008. with the remaining South American taxa being allocated to Brachycephalidae, and the West Indian and Mesoamerican direct-developing anurans belonging to Eleutherodactylidae and Craugastoridae, respectively (Hedges et al. 2008a).

Strabomantid frogs are arranged in two subfamilies. Phrynopus belongs to the large, diverse Strabomantinae, which contains 465 species and 10 genera distributed mainly in northwestern South America, where it is most diverse in Andean regions of Colombia, Ecuador, and Peru. Strabomantines are distin- 
guished from members of its smaller sister group, Holoadeninae ( 25 species in 6 genera), by the narrow terminal digits on the fingers and toes, and the usual absence of circumferential grooves in holoadenines. Strabomantines usually have expanded terminal digits and circumferential grooves. These morphological differences are not especially trenchant characters to distinguish among members of this speciose, widely distributed, and phenotypically challenging anuran clade; thus, it is hardly surprising that occasionally, molecular data are required for unequivocal allocation to subfamily, especially in the absence of comparative morphological data.

An unintended consequence of this major reorganization of direct-developing frogs is that we must reassess our morphological knowledge of the group, owing to the rearrangement of taxa. Phrynopus is a case in point. Currently, 21 species are recognized-auriculatus, ayacucho, barthlenae, bracki, bufoides, dagmarae, heimorum, horstpauli, juninenesis, kauneorum, kotosh, miroslawae, montium, nicoleae, oblivius, paucari, peruanus, pesantesi, tautzorum, tribulosus, and thompsoni (Chaparro et al. 2008, Hedges et al. 2008a). Several species formerly placed in Phrynopus were transferred to other genera. Among these are: bagrecito (Psychrophrynella), brunneus (Hypodactylus), columbianus (Niceforonia columbiana), cophites (Bryophryne), elassodiscus (Hypodactylus), fallaciosus (Hypodactylus), flavomaculatus (Lynchius), laplacai (synonym of wettsteini), lucida (Hypodactylus), nanus (Niceforonia nana), nebulanastes (Lynchius), nigrovittatus (Hypodactylus), parkeri (Lynchius), peraccai (Hypodactylus), pereger (Oreobates), peruvianus (part = Noblella peruviana ; part = Psychrophrynella $\mathrm{sp}$. nov.), spectabilis (synonym of Pleurodema marmorata), simonsii (Pristimantis), and wettsteini (Psychrophrynella). Osteological characters have figured significantly in taxonomic studies of Phrynopus and allied taxa beginning with Lynch's (1971) seminal work on leptodactylid frogs. Table 1 summarizes contributions to our osteological knowledge of these taxa (sensu lato) by Lynch (1971, 1975, 1986) and Cannatella (1984). Of the 18 species of Phrynopus listed as having been described or figured in previous publications, only three are retained in the genus today-Phrynopus peruanus, the type species of the genus, and $P$. dagmarae and $P$. kauneorum, two species recently described by Lehr et al. (2002a,b). Lynch (1975) provided a drawing of part of the pectoral girdle of the type species, $P$. peruanus. Lynch (1975) also provided illustrations of the bony skull for one other taxon, Niceforonia montia, which now is placed in Phrynopus. Thus, the irony of our osteological knowledge of Phrynopus is that we seemed to have a relatively firm grasp on it 30 years ago; however, today, we have available three renderings of the bony skull of one taxon, Phrynopus montium, a drawing of a portion of the pectoral girdle of the type species, $P$. peruanus, and drawings of the dentigerous processes of the vomers of $P$. dagmarae and $P$. kauneorum and the terminal phalanges of $P$. kauneorum.

Many collections contain undescribed species, and as Hedges et al. (2008a) observed, “... their analyses and resulting classification must be regarded as an initial effort waiting to be expanded and refined." Herein, we supplement their classification with the description of a new species of strabomantid anuran of the genus Phrynopus from Peru. The species was discovered in the collections of Louisiana State University Museum of Natural Science and is distinguished from all other Phrynopus by its unusually broad, sloping snout supported by an unusual configuration of the maxilla and premaxilla.

\section{Materials and Methods}

The taxonomy of strabomantid frogs follows that of Hedges et al. (2008a,b). The terminology specific to these anurans is adopted from Lynch and Duellman (1997) 
Table 1 - Summary of osteological data published in association with the generic name Phrynopus, with the current taxonomic status of the taxon noted. Taxa denoted with an asterisk are included in the strabomantid subfamily Holoadeninae, whereas all others are included in Strabomantinae (Hedges et al. 2008a).

\begin{tabular}{|c|c|c|c|}
\hline Current name & $\begin{array}{l}\text { Name used in } \\
\text { previous publication }\end{array}$ & Publication & Comments \\
\hline $\begin{array}{l}\text { Phrynopus } \\
\text { dagmarae }\end{array}$ & Phrynopus dagmarae & Lehr et al. (2002a: fig. 2) vomer & $\begin{array}{l}\text { Illustration \& } \\
\text { osteological characters }\end{array}$ \\
\hline $\begin{array}{l}\text { Phrynopus } \\
\text { kauneorum }\end{array}$ & $\begin{array}{l}\text { Phrynopus } \\
\text { kauneorum }\end{array}$ & $\begin{array}{l}\text { Lehr et al. (2002b: figs. } 2,3) \text { vomer and } \\
\text { terminal phalange }\end{array}$ & $\begin{array}{l}\text { Illustration \& } \\
\text { osteological characters }\end{array}$ \\
\hline Phynopus montium & Niceforonia montia & $\begin{array}{l}\text { Lynch (1971: fig. 104) bony skull in } 3 \\
\text { views; Lynch (1975) }\end{array}$ & $\begin{array}{l}\text { Illustrations \& } \\
\text { osteological characters }\end{array}$ \\
\hline $\begin{array}{l}\text { Phrynopus } \\
\text { peruanus }\end{array}$ & Phrynopus peruanus & Lynch (1975: fig. 13, pectoral girdle & Osteological characters \\
\hline $\begin{array}{l}\text { *Psychrophrynella } \\
\text { bagrecito }\end{array}$ & Phrynopus bagrecito & $\begin{array}{l}\text { Lynch (1986: fig. } 2 \mathrm{~A} \text {, a, dorsal/ventral } \\
\text { skull; fig. 3A, pectoral girdle; fig. } 3 \mathrm{C} \text {, } \\
\text { hyoid) }\end{array}$ & Osteological characters \\
\hline $\begin{array}{l}\text { Hypodactylus } \\
\text { brunneus }\end{array}$ & Phrynopus brunneus & Lynch (1975) & Osteological characters \\
\hline $\begin{array}{l}\text { Niceforonia } \\
\text { columbiana }\end{array}$ & $\begin{array}{l}\text { Phrynopus } \\
\text { columbianus }\end{array}$ & Lynch (1975) & Osteological characters \\
\hline $\begin{array}{l}\text { *Bryophryne } \\
\text { cophites }\end{array}$ & Phrynopus cophites & $\begin{array}{l}\text { Lynch (1975: fig. } 2 \mathrm{C} \text {, terminal } \\
\text { phalanges; fig. } 12 \text {, dorsal/ventral skull) }\end{array}$ & Osteological characters \\
\hline $\begin{array}{l}\text { Lynchius } \\
\text { flavomaculatus }\end{array}$ & $\begin{array}{l}\text { Phrynopus } \\
\text { flavomaculatus }\end{array}$ & Lynch (1975: fig. 9) skull in dorsal view & Osteological characters \\
\hline $\begin{array}{l}\text { *Psychrophrynella } \\
\text { wettsteini }\end{array}$ & Phrynopus laplacai & Lynch (1975) & Osteological characters \\
\hline $\begin{array}{l}\text { Hypodactylus } \\
\text { lucida }\end{array}$ & Phrynopus lucida & $\begin{array}{l}\text { Cannatella (1984: fig. } 4 \text {, dorsal/ventral } \\
\text { skull) }\end{array}$ & Osteological characters \\
\hline Niceforonia nana & Phrynopus nana & Lynch (1975) & Osteological characters \\
\hline $\begin{array}{l}\text { Lynchius } \\
\text { nebulanastes }\end{array}$ & $\begin{array}{l}\text { Phrynopus } \\
\text { nebulanastes }\end{array}$ & $\begin{array}{l}\text { Cannatella (1984: fig. } 4 \text {, dorsal/ventral } \\
\text { skull) }\end{array}$ & Osteological characters \\
\hline Lynchius parkeri & Phrynopus parkeri & $\begin{array}{l}\text { Lynch (1975: fig. 2A, terminal } \\
\text { phalanges; fig. 10, dorsal/ventral skull) }\end{array}$ & $\begin{array}{l}\text { Illustrations \& } \\
\text { osteological characters }\end{array}$ \\
\hline $\begin{array}{l}\text { Hypodactylus } \\
\text { peraccai }\end{array}$ & Phrynopus peraccai & Lynch (1975) & Osteological characters \\
\hline Oreobates pereger & Phrynopus pereger & Lynch (1975) & Osteological characters \\
\hline $\begin{array}{l}\text { *Noblella } \\
\text { peruviana }\end{array}$ & Phrynopus peruvianus & $\begin{array}{l}\text { Lynch (1975: fig. } 2 \mathrm{~B} \text {, terminal } \\
\text { phalanges; fig. 3: pectoral girdle; fig. } 11 \\
\text { dorsal/ventral skull) }\end{array}$ & $\begin{array}{l}\text { Illustrations \& } \\
\text { osteological characters }\end{array}$ \\
\hline Oreobates simonsii & Phrynopus simonsii & Lynch (1975) & Osteological characters \\
\hline $\begin{array}{l}\text { *Psychrophrynella } \\
\text { wettsteini }\end{array}$ & Phrynopus wettsteini & Lynch (1975) & Osteological characters \\
\hline
\end{tabular}


except that the term "dentigerous processes of vomers" is used instead of "vomerine odontophores." We follow the definitions of conditions of the tympanum by Lynch and Duellman (1997); the otic region was dissected in order to evaluate the condition of the tympanic annulus. Specimens were measured with digital calipers to the nearest $0.1 \mathrm{~mm}$ and include the following measurements: SVL (snout-vent length), tibia length, foot length (distance from proximal margin of inner metatarsal tubercle to tip of Toe IV), head length (from angle of jaw to tip of snout), head width (at level of angle of jaw), eye diameter, IOD (interorbital distance), upper eyelid width, internarial distance, and eye-nostril distance (straightline distance between anterior corner of orbit and posterior margin of external naris).

Comparative lengths of Toes III and V were determined when both were adpressed against Toe IV; lengths of Fingers I and II were estimated when adpressed against each other. Drawings were made with a stereomicroscope equipped with a camera lucida. Osteological data were gathered from radiographs of the new taxon, and comparisons were made with a cleared-and-stained congener, Phrynopus montium. Specimens were submerged in ethanol or isopropanol and photographed. Codes for museum collections are: KU = Natural History Museum, University of Kansas; LSUMZ = Louisiana State University, Museum of Natural Science; MHNSM = Museo de Historia Natural, Universidad Nacional Mayor de San Marcos; MTD = Museum für Tierkunde, Staatliche Naturhistorische Sammlungen Dresden. Comparative specimens examined are listed in Appendix I.

\section{Species Description}

Phrynopus lechriorhynchus sp. nov. (Figures 1-6)

Holotype - LSUMZ 31886 (Figure 1), an adult male from Punta de Esperanza on trail to
Huaylaspampa, above Acomayo, Departamento de Huánuco, Peru, obtained by Ted Parker in January 1975.

Paratype - LSUMZ 32308, juvenile from S Hualayspampa, Bosque Cutirragra ca. $2744 \mathrm{~m}$ (= 9100 feet), 18 July 1973 , obtained by D. A. Tallman.

Etymology - The specific epithet is derived from the Greek adjective lechrios, meaning "slanting," and the Greek noun rhynchos, meaning nose, in reference to the broad, spatulate snout and rostrum of this small frog.

Diagnosis - A strabomantid anuran distinguished by the following combination of characters: (1) Skin on dorsum finely shagreen; dorsolateral folds absent; skin on venter weakly areolate; discoidal fold absent; (2) tympanic membrane and tympanic annulus absent; (3) snout spatulate, long and depressed, broadly rounded in dorsal profile and sloping in lateral view; (4) upper eyelid without tubercles; upper eyelid width narrower than IOD; cranial crests absent; (5) dentigerous processes of vomers small, oblique; (6) males lacking vocal slits and nuptial pads; (7) Finger I shorter than Finger II; discs on fingers slightly expanded, marginal groove not discernable except on Finger III; (8) fingers without lateral fringes; (9) ulnar and tarsal tubercles absent; (10) heel lacking tubercles; inner tarsal fold present; (11) inner metatarsal tubercle ovoid, slightly larger than subconical outer metatarsal tubercle, elevated, slightly conical in lateral view; supernumerary plantar tubercles absent; (12) toes without lateral fringes; toe webbing absent; Toe V slightly shorter than Toe III; toe discs slightly smaller than those on fingers, marginal groove not discernable; (13) in preservative, dorsum mottled tan and brown with a white middorsal stripe, belly and chest tan with dark brown flecks, throat tan with a white middorsal stripe and minute brown spots; (14) SVL in single male $16.6 \mathrm{~mm}$.

As discussed above, Phrynopus lechriorhynchus is most likely to be confused with one of 


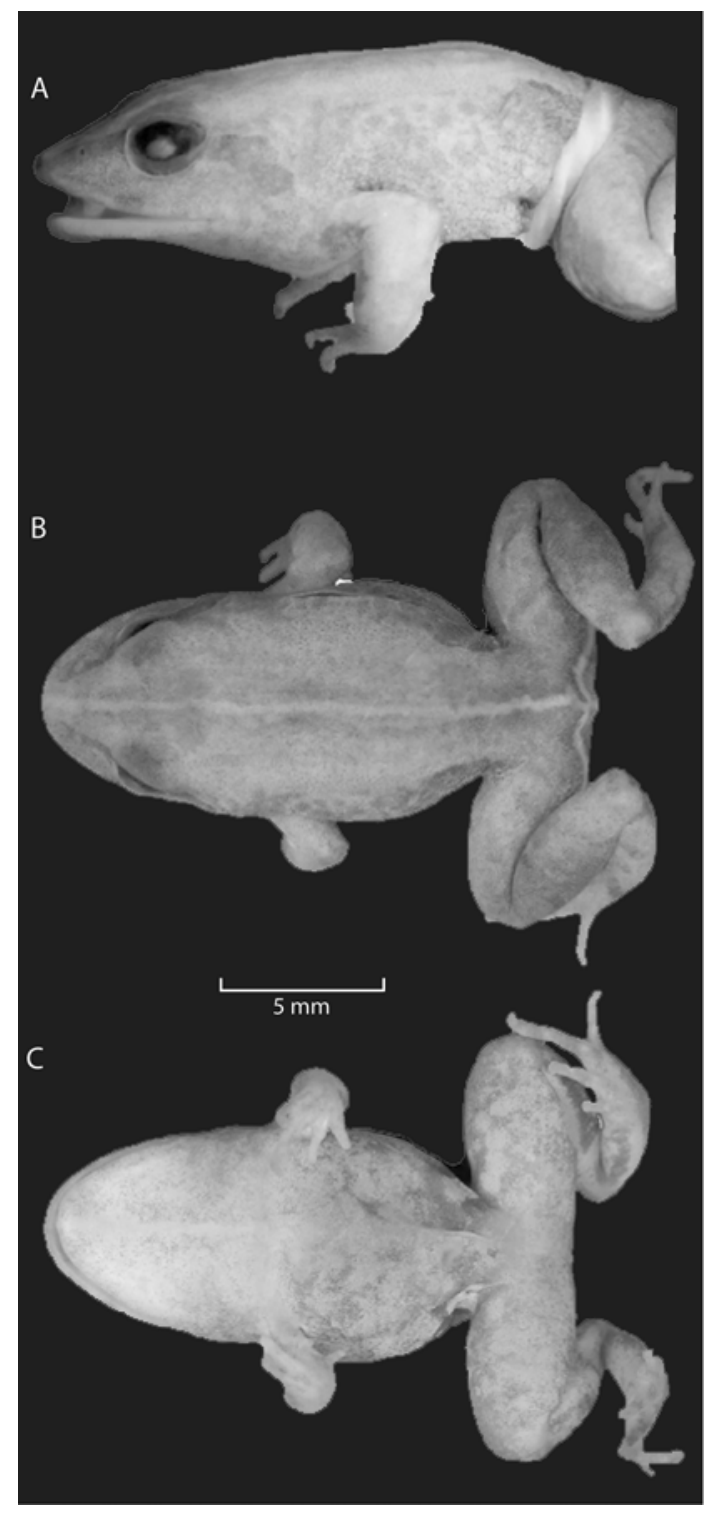

Figure 1 - Holotype of Phrynopus lechriorhynchus (LSUMZ 31886) in lateral (A), dorsal (B), and ventral $(C)$ views. Photos by E. Lehr.

the smaller species of Phrynopus, with which it shares a number of common external features. However, no other known Phrynopus possesses such a distinctly spatulate snout as does $P$. lechriorhynchus; the snout of this species is depressed (acuminate vs. blunt) in profile and the nostril is located about midway between anterior margin of the eye and the end of the snout (Figure 2A, B). Phrynopus lechriorhynchus also might be confused with male Hypodactylus nigrovittatus, which bear a fleshy protuberance on the end of the snout (Figure 2C, D). However, the snout in $H$. nigrovittatus is pointed, rather than broadly rounded, in dorsal view, and the protuberance, which is present only in males, lacks underlying skeletal support that is present in P. lechriorhynchus and described below.

Description of the holotype - Head as wide as body, slightly longer than wide (Figure 1); head width $36.1 \%$ SVL; head length $37.4 \%$ SVL; snout long and depressed, broadly rounded in dorsal view and sloping anteroventrally in lateral view (Figure 2A, B); top of head between eyes and nares slightly concave;
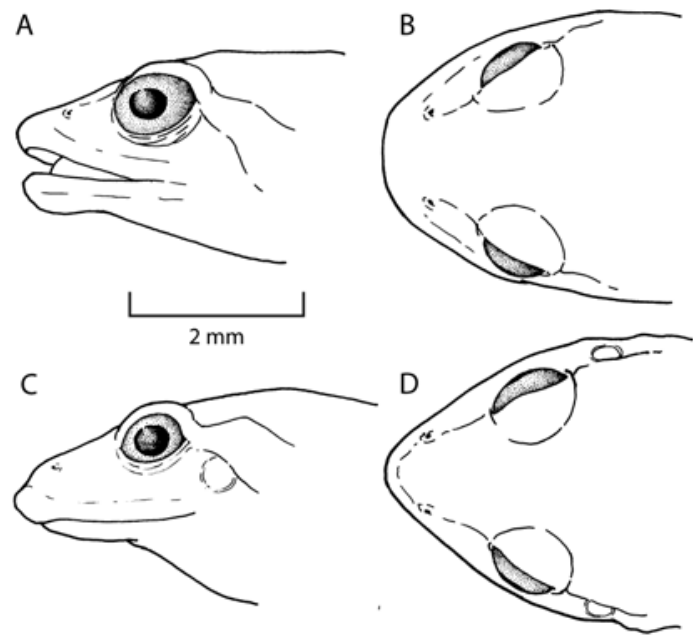

Figure 2 - Head of Phrynopus lechriorhynchus (holotype; LSUMZ 31886) in lateral (A), and dorsal (B) views. Note position of naris, which is located about midway between end of snout and anterior margin of eye. Lateral (C) and dorsal (D) views of head of male Hypodactylus nigrovittatus (KU 222017, male, $19.8 \mathrm{~mm}$ SVL), which bears a fleshy protuberance at the end of the snout. Note position of naris, which is closer to end of snout than it is to anterior margin of eye. Drawings by E. Lehr. 
eye diameter $150 \%$ eye-nostril distance; nostrils slightly protuberant, directed dorsolaterally; canthus rostralis straight in dorsal view, broadly rounded in section; loreal region concave; lips rounded; upper eyelid flat (artifact of preservation?), without tubercles; upper eyelid width $52.6 \%$ interorbital distance; tympanic membrane and annulus absent; supratympanic fold not distinct; two low, slightly enlarged post-rictal tubercles on each side of head. Choanae small, ovoid, not concealed by palatal shelf of maxilla; dentigerous processes of vomers thin, widely separated, situated posteromedial to choanae; each vomer bearing barely visible teeth in an oblique row; tongue $1.5 \times$ as long as wide, not notched behind, free posteriorly for half of its length.

Skin on dorsum finely shagreen with small tubercles dorsolaterally; dorsolateral folds absent (Figure 1); skin on flanks with small tubercles; skin on thighs, belly, chest, and throat weakly areolate, skin on other ventral surfaces smooth; discoidal fold absent; cloacal sheath short; large tubercles absent in cloacal region. Ulnar tubercles absent (Figure 3A); palmar tubercles slightly elevated, outer palmar tubercle bifid, approximately $2 \times$ the size of ovoid, thenar tubercle; subarticular tubercles indistinct; fingers without lateral fringes; Finger I shorter than Finger II; discs on fingers narrow; marginal grooves absent (Figure 3A).

Hind limbs slender, tibia length $40.4 \%$ SVL; foot length $39.8 \%$ SVL; upper surfaces of hind limbs weakly tuberculate; posterior and ventral surfaces of thighs weakly areolate; heel without tubercles; tarsus without tubercles or fold; inner metatarsal tubercle elevated, ovoid, about twice as large as round outer metatarsal tubercle (Figure 3B); plantar supernumerary tubercles indistinct; subarticular tubercles rounded, flat; toes without lateral fringes; webbing absent; Toe V slightly shorter than Toe III; discs on toes narrow, marginal groove absent; relative lengths of toes: $1<2<3<5<4$.

Measurements (in mm) of holotype: SVL 16.6; tibia length 6.7 ; foot length 6.6 ; head length 6.2 ; head width 6.0 ; diameter of eye 1.8 ; interorbital distance; 1.9 ; width of upper eyelid 1.0; internarial distance 2.0; eye-nostril distance 1.2.

\section{Coloration of holotype in preservative -} Dorsum mottled tan and brown with narrow white middorsal stripe from snout to cloaca; arms and legs mottled tan and brown; margin of upper lip with cream flecks separated by brown flecks; canthal and supratympanic stripes dark brown; flanks colored as dorsum but slightly darker; groin mottled tan and dark brown; anterior surface of thighs dark brown with few tan flecks; posterior surface of thighs dark brown, close to knee bend with three ovoid, white blotches on each side; concealed surfaces of shanks dark brown with irregularly shaped white blotches; belly and chest tan with dark brown flecks, throat tan with a white middorsal

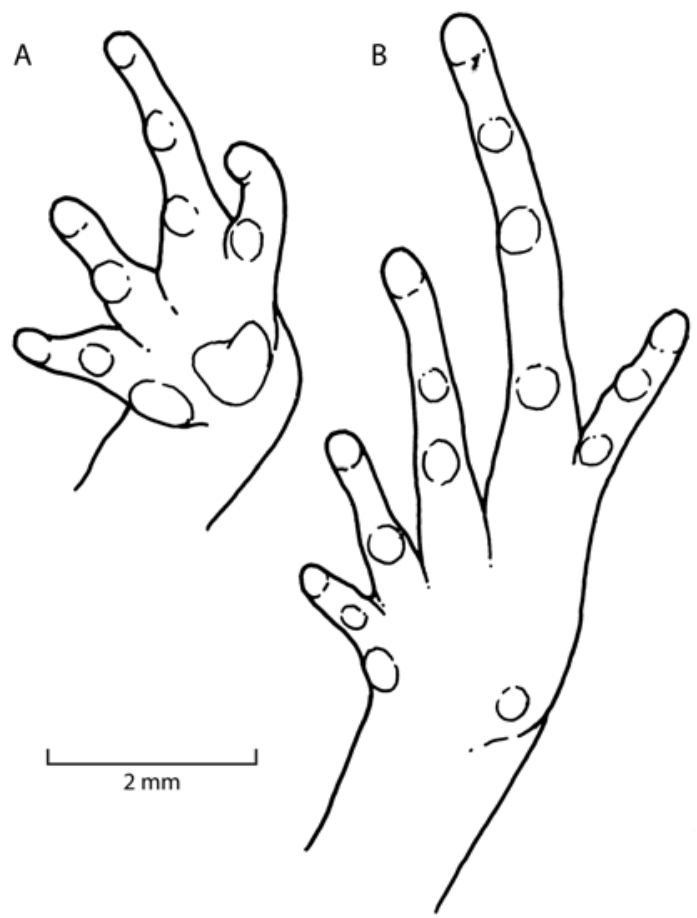

Figure 3 - Hand (A) and foot (B) of holotype of Phrynopus lechriorhynchus (holotype, LSUMZ 31886). Drawings by E. Lehr. 
stripe and minute brown spots; iris gray. Coloration of holotype in life unknown.

Variation - The single paratype is a juvenile in which the spatulate snout is not obviously developed; in other respects, the frog is morphologically identical to the holotype. Tuberculation of the ventral surfaces of the hand and feet is more distinct, probably because it is better preserved. The upper eyelid bears small tubercles. A marginal groove is visible on Finger III. The dorsum is brown with a white middorsal stripe bordered on both sides by dark brown extending from the tip of snout to cloaca; a broad, pale gray dorsolateral stripe extends from the posterior eyelid to insertion of legs. A midventral stripe runs from tip of lower lip to the posterior surfaces of thighs. A white stripe extends from the ventral surface of each arm across the chest, and another white stripe extends from the cloaca diagonally to proximal edge of posterior surface of each thigh.

Distribution - This species is known from two localities at elevations of 2740-2800 m on the eastern slopes of the Cordillera Oriental just north of the Río Huallaga in central Peru. Presumably, it occurs in remnants of humid montane forest.

Osteology - Cranium. The skull width is about equal to its length, and the greatest width is at the level of the articulation of the maxilla and quadratojugal at the posterior level of the optic fenestra and orbit (Figures 4, 5). The posterior end of the upper jaw lies anterior to the fenestra ovalis at the anterior corner of the otic capsule. The braincase is broad, nearly onethird the greatest width of the skull. The otic capsules are quadrangular, completely ossified dorsally with well-developed epiotic eminences; the anterior epiotic eminence is about 30\% longer than the posterior. The crista parotica is cartilaginous except for a small, ossified portion adjacent to the anterolateral corner of the otic capsule. The endocranial cartilage of the exoccipital and prootic regions of the braincase seems to be completely mineralized. The occipital condyles are widely separated and stalked. Dorsally, the paired parietal fontanelles are separated from one another by the taenia tecti medialis and from the large frontal fontanelle by the taenia tecti transversalis. The braincase is roofed by paired frontopairetal bones, the limits of which cannot be distinguished in the radiographs; likewise, the shape of the nasals is difficult to determine. Ventrally, a large prootic foramen and small oculomotor foramen are visible in the prootic. The sphenethmoid is complete dorsally and ventrally. In ventral and lateral views, its posterior margin can be seen to lie at about the midlevel of the orbit. The sphenethmoid contributes to the posterior walls of the olfactory capsule, and extends about one-third the distance lateral toward the maxilla. The rostrum (i.e., that part of the cranium anterior to the braincase) is extraordinarily large in this species, accounting for nearly $30 \%$ the length of the skull. However, close examination of the radiographs reveals a peculiarity. The olfactory capsules occupy only the posterior two thirds of this space. The anterior end of the snout is composed of broad premaxillae that bear large alary processes that are deflected at a steep posterior angle (Figure 4).

The maxillary arcade is complete, but the articulation between the maxilla and quadratojugal is weak (Figure 4). Teeth are present on the maxillae and premaxillae. A moderate palatal shelf is evident on the maxilla. The premaxilla is distinguished by extraordinarily hypertrophied medial palatine processes and lateral palatine processes. These processes, together with the broadly splayed alary process configure the premaxilla, which forms a terminal rostral bone that lies anterior to the olfactory capsule on each side (Figures 4, 5). The maxilla bears a well-developed pars facialis anterior to the orbit that covers the lateral aspect of the olfactory capsule. The pterygoid is well developed with a slender, approximately straight anterior ramus that parallels the 
Trueb and Lehr

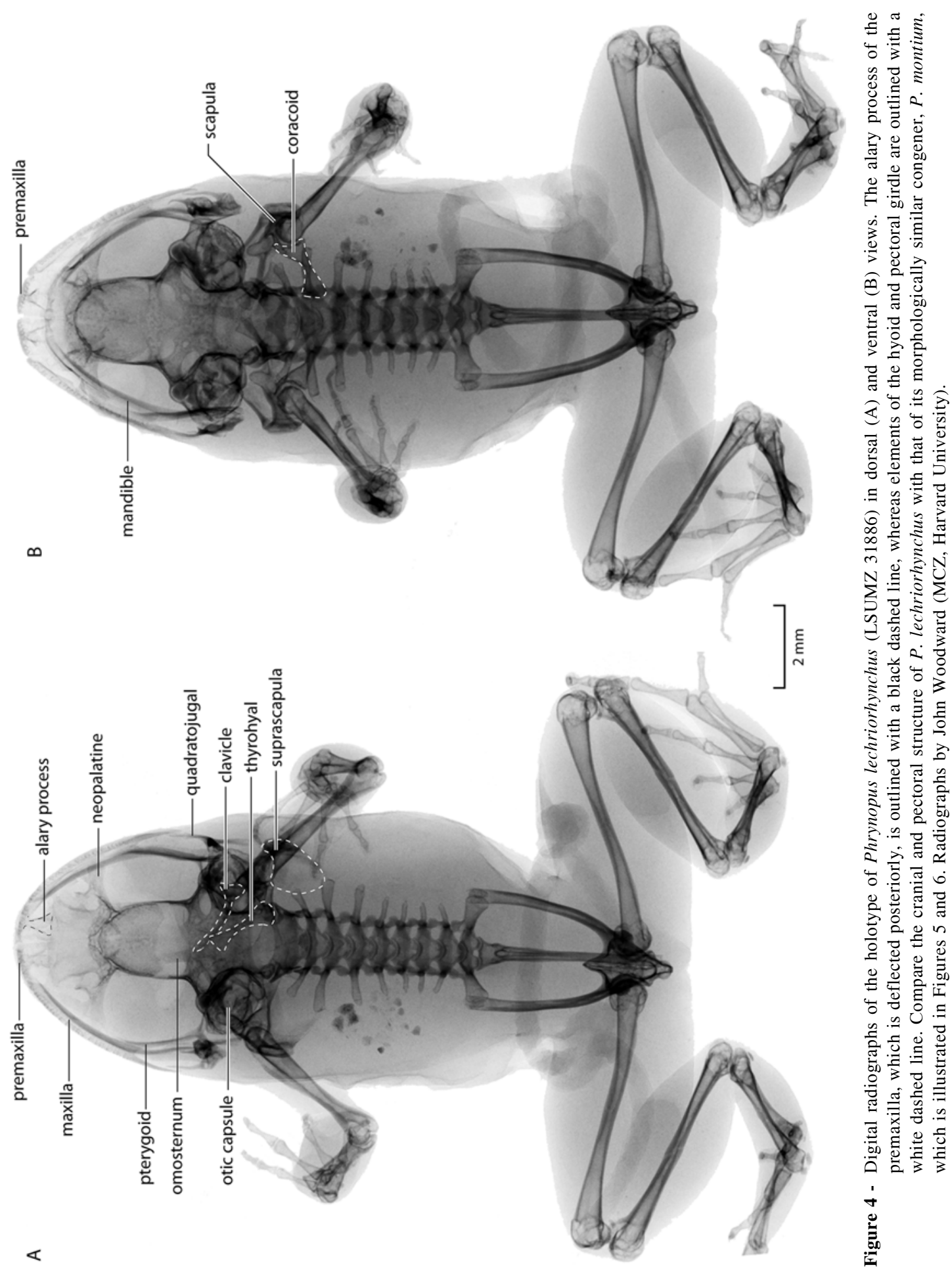


A

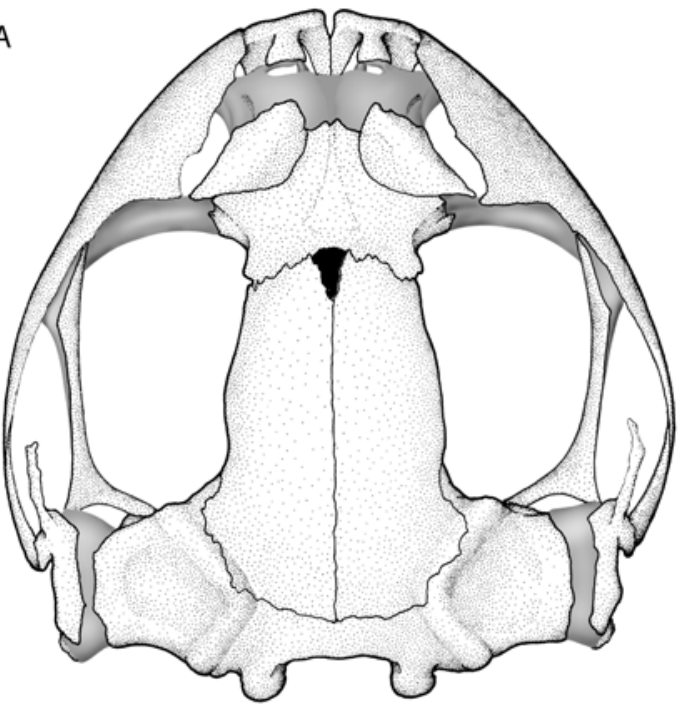

C
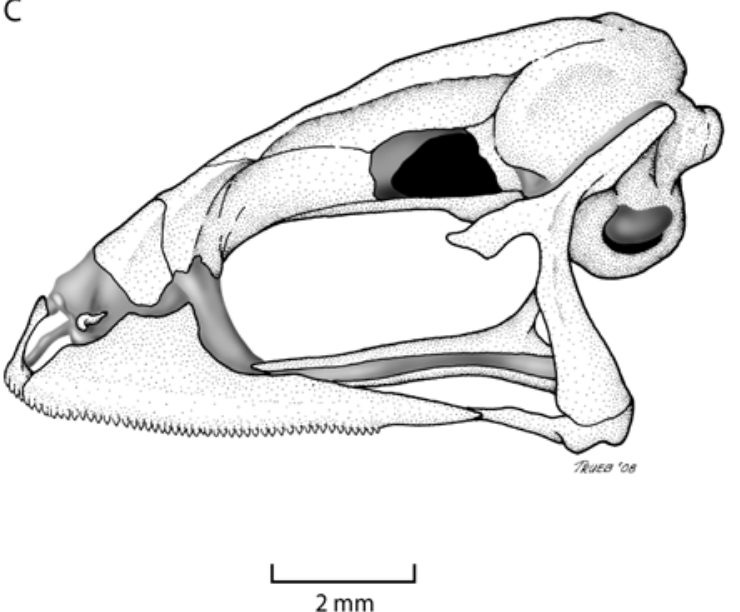

B
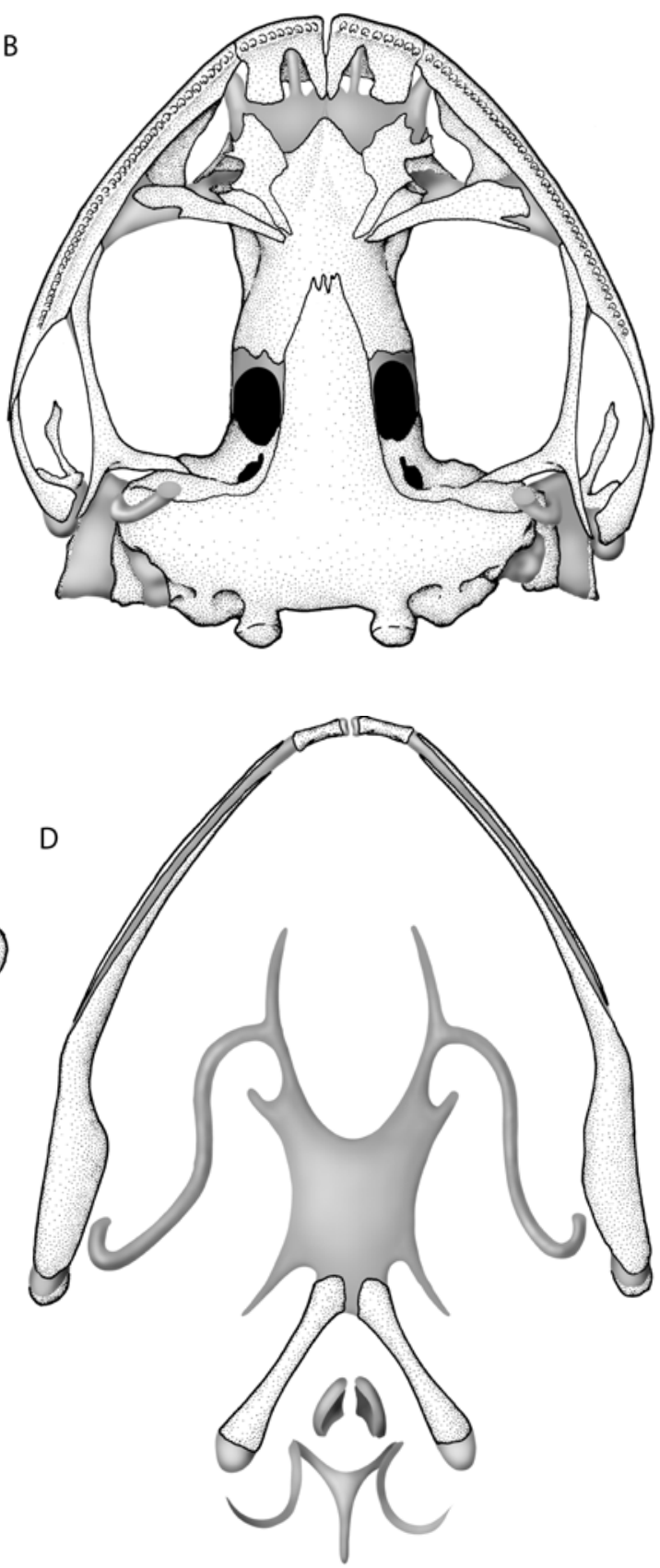

Figure 5 - Cranial osteology of Phrynopus montium (KU 206652, female, $24.2 \mathrm{~mm} \mathrm{SVL}$ ). Dorsal (A), ventral (B), and lateral (C) views of skull. (D) Ventral aspect of mandible and hyoid apparatus. Bones are stippled and cartilage is shown in gray. Cranial morphology resembles that of P. lechriorhynchus. However the snout is less spatulate; the premaxillae are slightly narrower, and the alary processes of premaxilla are smaller and not deflected posteriorly at such a great angle as in P. lechriorhynchus. 
braincase. The medial ramus of the pterygoid abuts the anterolateral margin of the otic capsule ventrally and is approximately the same length as the more slender posterolateral ramus of the bone. The squamosal is surprisingly well developed; the otic ramus caps the lateral margin of the crista parotica and the zygomatic ramus is a short, blunt blade extending about one-quarter the way to the maxilla. The ventral ramus is stout, completely investing the lateral aspect of the palatoquadrate.

The parasphenoid is robust. The width of the cultriform process is about one-third that of the braincase; the process tapers slightly anteriorly and its anterior terminus is broadly separated from the anterior margin of the orbit. The posterolateral alae are broad, completely flooring the otic capsules, but the exact limits are difficult to determine owing to synostosis. A tympanic annulus is absent, as is the plectral apparatus; however, a cartilaginous operculum lies in the fenestra ovalis.

The anterior palatal region is distinguished by well-developed neopalatines, anterior ossification of the sphenethmoid in the olfactory region, and elimination of vomerine dentition. The vomers are present as flat palatal bones, but lack dentigerous processes (Figure 5B).

Axial column. The vertebral column is composed of eight procoelous presacral vertebrae (Figure 4). The transverse processes of Prescrals II and III are slightly expanded distally; those of Presacral II are oriented anterolaterally, whereas those of III are slightly curved and lateral in orientation. The relative sizes (overall width) of the vertebral elements is as follows: $\mathrm{I}<\mathrm{VI}=\mathrm{VII}=\mathrm{VIII}<\mathrm{V}<\mathrm{II}<\mathrm{IV}=$ sacrum $<$ III. The sacral diapophyses are narrowly expanded, with the distal width being only about twice that of the base. The leading edge of the diapophysis is straight and forms nearly a right angle with the longitudinal axis of the body, whereas the posterior margin is curved and describes an acute angle with the body axis. The sacrum has a bicondylar

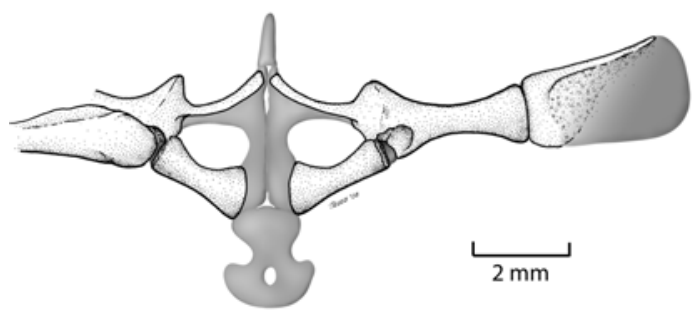

Figure 6 - Pectoral girdle of Phrynopus montium (KU 206652, female, $24.2 \mathrm{~mm} \mathrm{SVL}$ ) in ventral view. The scapula and suprascapula have been deflected into the ventral plane for the purposes of illustration. Bones are stippled and cartilage is shown in gray.

articulation with the urostyle, which bears a simple dorsal flange.

Pectoral girdle. Although the pectoral girdle clearly is arciferal in origin, it seems to be functionally firmisternal (Figure 6). The clavicle is moderately robust and uniform in width along the procoracoid cartilage (Figure 4). The medial ends of the clavicles are blunt and distinctly separated from one another. The medial arms of the clavicles are slightly concave and oriented anteromedially such that their tips lie at a level slightly anterior to that of the lateral head of the fused clavicle and pars acromialis of the scapula. The omosternum is a slender spindle of cartilage (Figures 4,6). The clavicle seems to be synostotically united with the coracoid by means of mineralization of the procoracoid cartilage in the region of the glenoid fossa. The coracoid is a robust bone. The width of the bone at the glenoid cavity is about $1.5 \times$ that of the midshaft width, whereas that at the sternal end is more than $2 \times$ the midshaft width; the length of the bone is about twice the width at the sternal end. The pars acromialis of the scapula is fused to the clavicle and separated by a distinct cleft from the pars glenoidalis. Both the anterior and posterior margins of the scapula are broadly concave; the slender midshaft width is only about half the width of the dorsal scapular margin, which in 


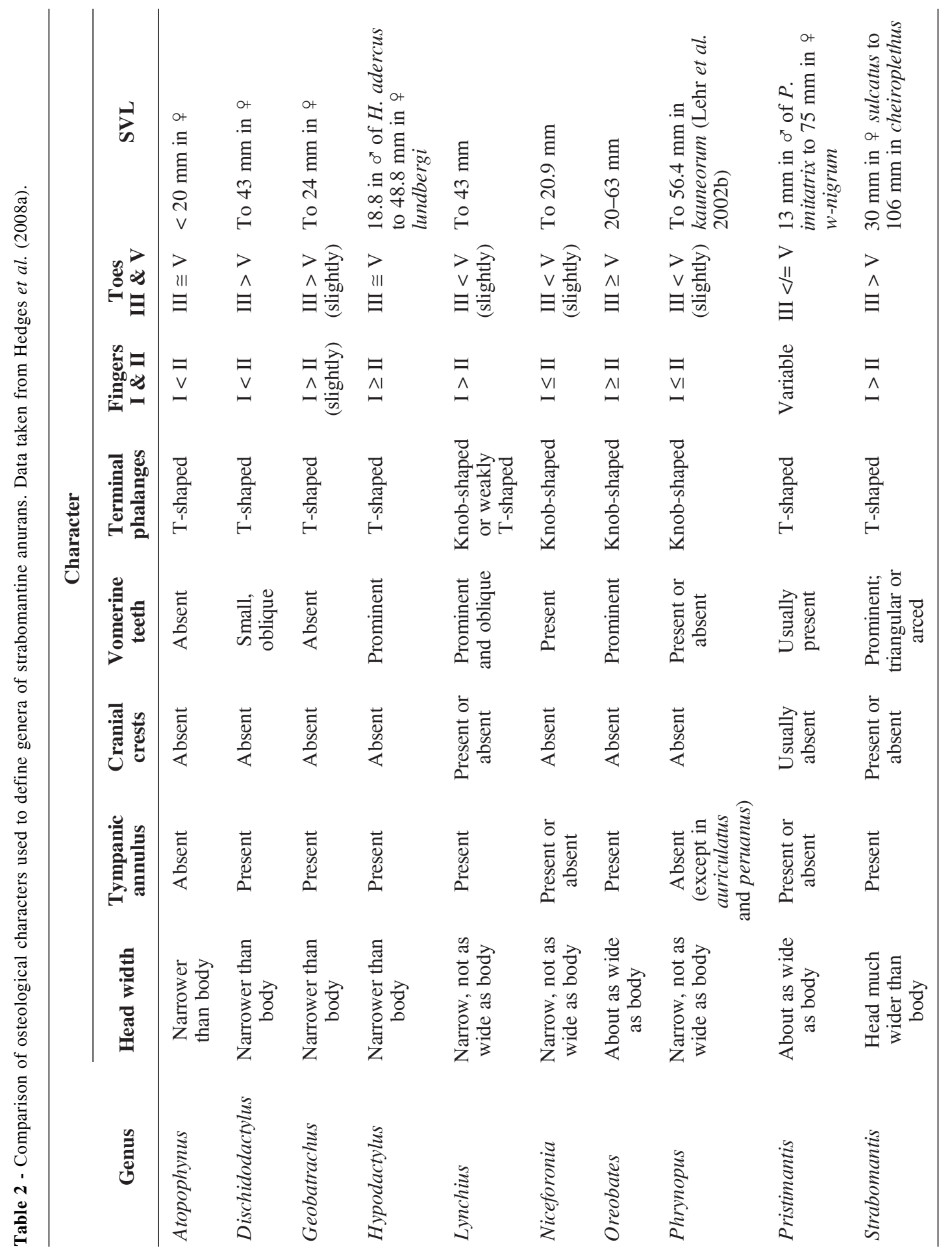


turn, is narrower than the ventral portion of the bone. The suprascapula is narrow, with the dorsal margin being only about $30 \%$ broader than the ventral margin. The cleithrum is evident as a narrow band of bone along the anterior margin that grades into mineralization of the suprascapular cartilage posteroventrally.

\section{Discussion}

The results of molecular studies (Hedges et al. 2008a,b) reveal that Phrynopus is a member of a clade composed of 10 genera with a center of diversity in northwestern South America. The osteological characters that have been used to diagnose these taxa are listed in Table 2. Phrynopus is one of four genera that possesses knob-shaped terminal phalanges, the others being Lynchius, Niceforonia, and Oreobates. Based on the generalized and miscellaneous osteological characters listed in this table, Phrynopus is not clearly distinct from Niceforonia. It differs from Lynchius primarily in the relative lengths of Fingers I and II, and from Oreobates in the relative lengths of Fingers I and II, and III and V.

Published illustrations of the skulls of Lynchius flavomaculatus and L. parkeri (Lynch 1975: figs. 9, 10), and L. nebulanastes (Cannatella 1984: fig. 4, right) permit us to identify characters that distinguish Lynchius and Phrynopus. The skulls of Lynchius are robust and much wider than long (length $86 \%$ width in flavomaculatus and parkeri; $84 \%$ in nebulanastes), whereas those of Phrynopus are about equal in width and length. All of these species have well-ossified skulls with large nasals that overlap the ossified sphenethmoid and articulate with one another medially or are narrowly separated (nebulanastes) and that cover most of the lateral portion of the olfactory capsule, whereas the nasals are much smaller in Phrynopus. The frontoparietals are large, articulated medially or narrowly separated (nebulanastes), and exostosed in L. flavomaculatus; they are similar in Phrynopus, but show no tendency toward exostosis.
In both Lynchius and Phrynopus, the otic capsules are well ossified and synostotically united with the cristae paroticae. The squamosal articulates with the crista parotica in each species except nebulanastes, in which it is narrowly separated from the bony crista, as it is in Phrynopus. Lynchius nebulanastes differs from its congeners and Phrynopus in having incomplete ossification of the exoccipital; there are gaps in the ossification dorso- and ventromedially, as well as along the posterior epiotic eminence at the union of the exoccipital and prootic. Neither Lynch (1975) nor Cannatella (1984) illustrated the plectral complex; so, nothing can be added about this.

The maxillary arcades of Lynchius and Phrynopus differ significantly, although in both genera they are dentate and robust, bearing well-developed facial flanges and stout quadratojugals. In Lynchius, the alary processes of the premaxillae are more or less vertical, whereas in Phrynopus, they are deflected posteriorly. The mandible is long, with the angle of the jaw lying at about the level of the fenestra ovalis or slightly posterior to it in Lynchius; a transverse line projected across a dorsal view of the skull at the level of the angle of the jaw would transect the posterior epiotic eminence in Lynchius, whereas the same metric in Phrynopus would transect the anterior epiotic eminence. The maxillae bear moderately well developed palatal shelves in both genera, and the premaxillae are characterized by extraordinarily large medial and lateral palatine processes (condition unknown in L. flavomaculatus). (Alternately, some authors might describe this condition as an extraordinarily wide palatal shelf that is deeply incised.) The sizes of these palatal components of the premaxilla seem more exaggerated in Phrynopus, perhaps by comparison with the relatively more delicate pars palatina of the adjacent maxilla in this genus than in Lynchius.

The dentate vomers of Lynchius are well developed in parkeri and nebulanastes, with the posterior parts of the vomers lying at the level 
of the neopalatines and anterior end of the cultriform process of the parasphenoid. Phrynopus, in contrast, lacks dentigerous processes of the vomers, although the posterior vomerine processes terminate adjacent to the neopalatines. The cultriform process of Phrynopus is much shorter than that of $L$. parkeri and $L$. nebulanastes, in which the anterior terminus of this bone lies at the anterior margin of the orbit at the level of the neopalatines. In both of the latter species, the cultriform process is narrower at its base than it is at mid-orbit; anteriorly, it gradually tapers in width. The pterygoid is robust in both Lynchius and Phrynopus, with the anterior ramus articulating with the maxilla in the anterior part of the orbit.

Lynch (1971: fig. 104) provided the first illustrations of the skull of Phrynopus montium in his account of Niceforonia montia; these drawings are based on specimens stained only for bone and thus, are supplemented herein with drawings of a specimen showing cartilage and bone. The latter, of course, provides more information about a greater range of body parts, but there is remarkable parity in our observations of the bony elements of the skull. We see a slightly greater posterior deflection of the alary processes of the premaxillae, a somewhat different shape of the pars facialis of the maxilla, a shorter maxillary arcade, and a less robust quadratojugal than Lynch illustrated; the length the upper jaw and even the deflection of the alary processes (in dorsal view) can be a function of the tilt of the plane in which the specimen is viewed. We suspect that this accounts for the discrepancy because the length of the maxillary arcade appears significantly shorter in his ventral view of the same specimen than it does in his dorsal view. We also think that he simplified his interpretation of the neopalatines or could not distinguish them from the underlying cartilage in the region of the planum antorbitale.

Lynch (1975) redescribed Phrynopus peruanus, the type species of the genus, and provided drawing of the zonal elements of the pectoral girdle based on a dissection of a preserved specimen. Based on his illustration
(Lynch 1975: fig. 13), P. peruanus has an arciferal girdle with broadly overlapping epicoracoid cartilages. The coracoid is a short, stout element that is slightly wider at is glenoid end than its sternal end; the coracoids are broadly separated from one another by a width equivalent to the length of the coracoid bone. In contrast, in the girdles of $P$. montium and $P$. lechriorhynchus, the epicoracoid areas are narrower, and coracoids longer; in P. montium, it is possible to discern that the epicoracoids are partially fused to one another medially. Lynch depicts a simple, broad sternum with a shallowly notched posterior margin for $P$. peruanus. The sternum of Phrynopus montium, in contrast, has lateral notches and a curved posterior margin. All three taxa have simple, spindle-like cartilaginous omosterna and robust clavicles, with the medial tips of the clavicular arms lying anterior to the level of the fused heads of the clavicle and pars acromialis of the scapula.

As morphologists and taxonomists, it is gratifying to note that the extensive reorganization based on molecular data of these speciose and often troublesome anurans has yielded an arrangement that seems to make sense-at least for the few taxa about which we know something osteologically. Thus, among the knob-fingered genera, Lynchius can be distinguished from Phrynopus, and both genera, in turn, seem to have combinations of features that may prove to distinguish them from other genera. Although it is more difficult to gather data about bones, they have fascinating functional and evolutionary stories to tell. It is hoped that the information provided in Tables 1 and 2, along with the results of this paper, will encourage other evolutionary biologists to investigate the osteological diversity of strabomantid anurans.

\section{Acknowledgments}

We are grateful to W. E. Duellman for his thoughtful commentary on a preliminary draft 
of this manuscript. Specimens were kindly loaned by Chris Austin (LSUMZ), and John Woodward (MCZ) and Andrew Campbell (KU) provided radiographs of specimens. Lehr's research was supported by a postdoctoral grant from the Alexander von Humboldt-Foundation, a DFG grant, and an Ernst Mayr Grant provided by the Museum of Comparative Zoology. Trueb's research was supported by a grant from the National Science Foundation, EF-0334928.

\section{References}

Cannatella, D. C. 1984. Two new species of the leptodactylid frog genus Phrynopus, with comments on the phylogeny of the genus. Occasional Papers of the Museum of Natural History, The University of Kansas 113: 1-16.

Chaparro, J. C., J. M. Padial and I. De la Riva. 2008. Two sympatric new species of Phrynopus (Anura: Strabomantidae) from Yanachaga Chemillén National Park (central Peruvian Andes). Zootaxa 1761: 49-58.

Frost, D. R., T. Grant, J. Faivovich, R. H. Bain, A. Haas, C. F. B. Haddad, R. O. de Sá, A. Channing, M. Wilkinson, S. C. Donnellan, C. J. Raxworthy, J. A. Campbell, B. L. Blotto, P. Moler, R. C. Drewes, R. A. Nussbaum, J. D. Lynch, D. M. Green, and W. C. Wheeler. 2006. The amphibian tree of life. Bulletin of the American Museum of Natural History 297: 1-371.
Hedges, S. B., W. E. Duellman and M. P. Heinicke. 2008a. New World direct-developing frogs (Anura: Terrarana): molecular phylogeny, classification, biogeography, and conservation. Zootaxa 1737: 1-182.

Hedges, S. B., W. E. Duellman and M. P. Heinicke. 2008b. A replacement name for Isodactylus. Zootaxa 1795: 67-68.

Lehr, E., C. Aguilar and G. Köhler. 2002a. Two sympatric new species of Phrynopus (Anura: Leptodactylidae) from a cloud forest in the Peruvian Andes. Journal of Herpetology 36: 208-216.

Lehr, E., C. Aguilar and J. H. Córdova. 2002b. Morphological and ecological remarks on Phynopus kauneorum (Amphibia, Anura, Leptodactylidae). Zoologische Abhandlungen Museum für Tierkunde Dresden 52: 71-75.

Lynch, J. D. 1971. Evolutionary relationships, osteology, and zoogeography of leptodactyloid frogs. University of Kansas Museum of Natural History Miscellaneous Publication 53: 1-238.

Lynch, J. D. 1975. A review of the Andean leptodactylid frog genus Phrynopus. Occasional Papers of the Museum of Natural History, The University of Kansas 35: $1-51$.

Lynch, J. D. 1986. New species of minute leptodactylid frogs from the Andes of Ecuador and Peru. Journal of Herpetology 20: 423-431.

Lynch, J. D. and W. E. Duellman. 1997. Frogs of the genus Eleutherodactylus in western Ecuador. Systematics, ecology, and biogeography. The University of Kansas Natural History Museum Special Publication 23: 1-236.

\section{Appendix I - Comparative Material Examined}

Hypodactylus nigrovittatus: ECUADOR: NAPO: S slope Cordillera del Due above Río Coca, 1150 m: KU 123503-42, 123544-65. PERU: LoRETo: jct. Río Sucusari \& Río Napo: KU 220354; jct. Río Yanamono \& Río Amazonas: KU 220355, KU 220447-48; San Jacinto, 175-190 m: KU 22017-18; 1.5 km N Teniente López, 310-340 m: KU 222019-20.

Noblella duellmani: PERU: PASco: Cillapata (approximately $1.5 \mathrm{~km}$ NNE Auquimarca), $2900 \mathrm{~m}$ : MHNSM 19856 (holotype).

Phrynopus montium: PERU: Junín: Monaynioc, 72 km NE Tarma, 3660 m: KU 206650-52.

Pristimantis cruciocularis: PERU: Junín: Pampa Hermosa, 1540 m: MHNSM 18685 (holotype).

Pristimantis flavobracatus: PERU: Pasco: Km 34 on road from Oxapampa to Yaupi, $1770 \mathrm{~m}$ : MHNSM 19871.

Pristimantis rhabdocnemus: PERU: PASCO: $2.9 \mathrm{~km} \mathrm{~N}$ and $5.5 \mathrm{~km}$ E (airline) of Oxapampa, $2600 \mathrm{~m}$ : KU 291646 (holotype), 291651 (paratype), 291647-291650, 291652-291656. 